\title{
On condition factor measurements in Pacific herring larvae
}

\author{
H. v. Westernhagen \& H. Rosenthal \\ Biologische Anstalt Helgoland (Zentrale); Palmaille 9, D-2000 Hamburg 50, \\ Federal Republic of Germany
}

\begin{abstract}
Condition factors $\left(\mathrm{CF}=\mathrm{mg} \cdot \mathrm{mm}^{-3} \cdot 100\right)$ of Pacific herring larvae from Departure Bay, Canada, were determined from two larval year classes and compared for yolk sac and post-yolk sac feeding larvae. Decline in condition factors for yolk sac larvae was similar in both years. Subsequent increase of condition factors after passing the transitional phase between loss of yolk and first feeding was identical for both years. The occurrence of emaciated larvae in 1976 was attributed to poor food supply during the "critical period" (the time of first food uptake).
\end{abstract}

\section{INTRODUCTION}

The length/weight relationships of fishes were used as early as 1948 for assessment of the fishes' condition and condition factors (CF) were determined as weight in grams multiplied with 100 and divided by standard length in millimeters to the third power (CF $\left.=\mathrm{g} \cdot \mathrm{l}^{-3} \cdot 100\right)$ in order to determine the state of nutrition of a fish. The higher the condition factors of a given species, the more truncate the fish. Within one species high condition factors indicate well fed individuals. Beckmann (1948) made use of the condition factor in the description of the condition of seven Michigan fishes. The condition factor or coefficient of condition has also been mentioned by Rounsefell \& Everhardt (1953) in their treatise on fishery science as expressing the ". . relative wellbeing of the fishes". Thus condition factors are generally used to indicate suitability of an environment or to compare the same species of fish from one area with those from another with different environmental conditions.

Recently, condition factors have been used to determine the condition of fish larvae as well (Hempel \& Blaxter, 1963; Vilela \& Zijlstra, 1971; Ehrlich et al., 1976) and an attempt has been made to relate the condition of, for instance, larval plaice to feeding conditions and subsequent success in recruitment (Shelbourne, 1957). The hypothesis, that some relation exists between larval condition and recruitment, was refuted by Vilela \& Zijlstra (1971) while investigating the condition of North Sea herring larvae and its relation to year-class success.

In order to provide more insight into the understanding of the development of condition factors in yolk sac and post-yolk sac larvae, this study presents the development of larval condition in Pacific herring caught at the same sampling site during the years 1974 and 1976. 


\section{MATERIAL AND METHODS}

We collected data on dry weight and total length of Pacific herring larvae, Clupea harengus pallasi, at the Nanaimo Pacific Biological Station, Canada, during April and beginning of May in the years 1974 and 1976. Larvae were attracted at night with a $300 \mathrm{~W}$ light bulb suspended directly over the water surface. Larval fish were then caught with a pail and after transfer to the laboratory $(5 \mathrm{~min})$ anaesthetized and measured. The measured specimens were dried at $60{ }^{\circ} \mathrm{C}$ on silicon coated glass slides from which they could be easily removed for later dry weight determination. Condition factors of larvae

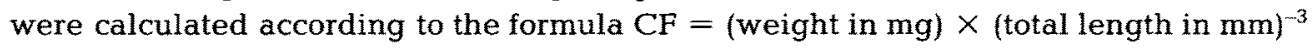
$\times 100$. In the literature multiplication with 1000 is also commonly used; this affects the factor, however, only in the decimal place.

Yolk volumes were calculated by measuring the large (a) and small (b) diameter of the yolk and applying the data to the formula $V$ (volume) $=4 / 3 \pi \mathrm{b}^{2} \mathrm{a}$.

\section{RESULTS AND DISCUSSION}

The development of the 1974 and 1976 condition factors is depicted in Figure 1 for yolk sac and post-yolk sac larvae. During the yolk sac phase larvae continuously lose weight. They start gaining weight shortly after the onset of feeding. Thus both phases have been considered separately and linear regressions have been calculated for each phase. As can be seen from the regression equation (Fig. 1), in both groups of yolk sac larvae the slopes of the regression lines indicating the development of the condition factors are almost identical $(-0.00571$ in $1974 ;-0.00574$ in 1976).

Although we can assume that the larvae investigated during this study were derived from the same parental stock (spawning of herring takes place every year in a nearby cove), we found considerable differences in condition factors within the same length groups (Fig. 1). These pronounced variations are caused by the size of the yolk sac as shown in Figure 2. The yolk adds to the weight without increasing the length of the larvae (see Blaxter \& Hempel, 1963). In the groups sized 8.75 to $10.25 \mathrm{~mm}$ there exists an almost linear relationship between condition factors and yolk sac volume. The larger the yolk sac the greater the condition factors at given lengths (Fig. 2). With increasing length and decreasing yolk sac volume condition factors tend to become smaller and more uniform (Fig. 1). Variations are low at the beginning of feeding shortly after yolk absorption (Fig. 1, Table 1). This means that most of the larvae, after having resorbed their yolk, start with almost the same condition factor at the time of first feeding, having a total length of approx, $11.0 \mathrm{~mm}$. Those larvae which initiated feeding early still preserve some of their yolk remnants, as can be taken from Figure 1a for the 9.5 to 10.5 $\mathrm{mm}$ larvae and from Figure $1 \mathrm{~b}$ for the 10.5 to $11.5 \mathrm{~mm}$ (Fig. 1b) larvae and thus display higher mean condition factors than larvae of the same length without yolk vestiges when comparing open and closed circles in Figure 1. This phenomenon has already been described by Blaxter (1971) for Clyde herring larvae.

We also notice in Figure 1 that post-yolk sac larvae, sized between 9.0 and $11.0 \mathrm{~mm}$ still lose weight, growing only in length, a phenomenon also observed by Blaxter (1971) and by Vilela \& Zijlstra (1971) in herring larvae from the Clyde area and the central North Sea. This phase probably reflects the process of learning how to prey and the improvement of snapping success (Rosenthal \& Hempel, 1970; Blaxter \& Staines, 1971) 


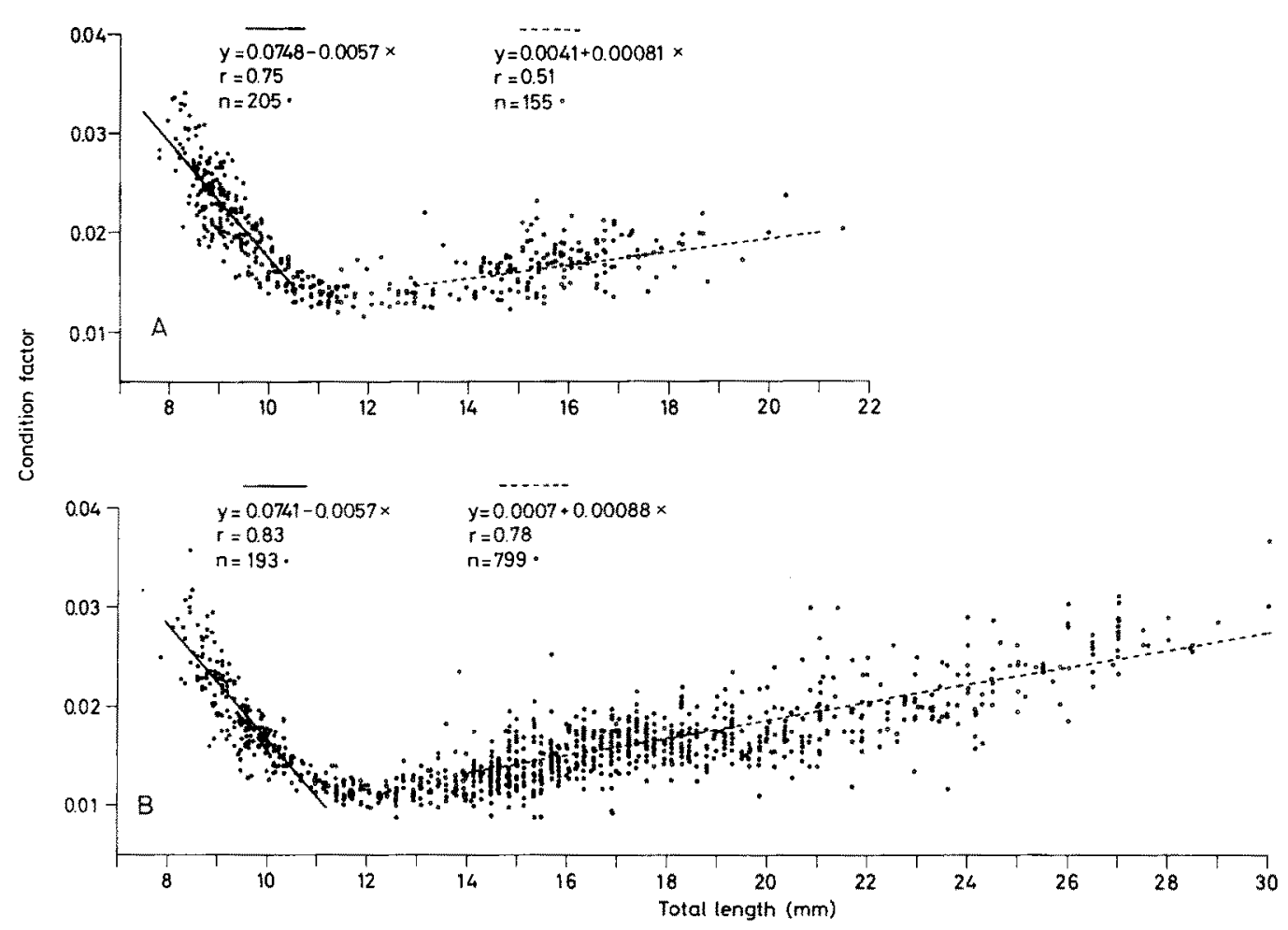

Fig. 1. Change of condition factor ( $\left.\mathrm{mg} \cdot \mathrm{mm}^{-3} \cdot 100\right)$ with growth in herring larvae from Departure Bay, Canada. Full circles: yolk sac larvae; open circles: post-yolk sac larvae; mean surface water temperature during the yolk sac phase was $9.3-9.4^{\circ} \mathrm{C}$. a: $1974 ; \mathrm{b}: 1976$. Broken lines indicate feeding larvae, starting at $13.00 \mathrm{~mm}$ for 1974 and $14.00 \mathrm{~mm}$ for 1976

during the time between loss of yolk and first food uptake when more energy is consumed by the swimming larvae than is taken up via food.

Although the 1974 and 1976 larvae start with different condition factors (see Table 1, $8.45 \mathrm{~mm}$ ), Figure 1 shows the rate of decline in condition factors of yolk sac larvae to be identical in 1974 and 1976 . When the larvae attain the length of $8.8 \mathrm{~mm}$, condition factors in both year classes are already very much alike $(1974: 0.0247 ; 1976: 0.0251)$ and after reaching a total length of $10.00 \mathrm{~mm}$ their common mean condition factor is 0.016 . This is the moment of first feeding and after the transitional phase of first food uptake when condition factors drop to as low as 0.0137 in 1974 and 0.012 in 1976 , the condition of the larvae improves at a total length of around $13.00 \mathrm{~mm}$ (1974) and $14.00 \mathrm{~mm}$ (1976).

There arises the question why condition factors of the 1976 larvae had to drop to 0.012 before they started to improve. A possible explanation is that, although the surface water temperature was the same in both years, there was a major phytoplankton bloom in April 1974 (Kennedy \& LeBrasseur, 1977), thus food availability must have been better in 1974 during the time of first feeding, the "critical period" sensu Hjort (1914). Once food availability became better for the 1976 larvae too, the progress of growth of this year class was practically identical to that displayed by the 1974 animals. Figure 1 indicates 


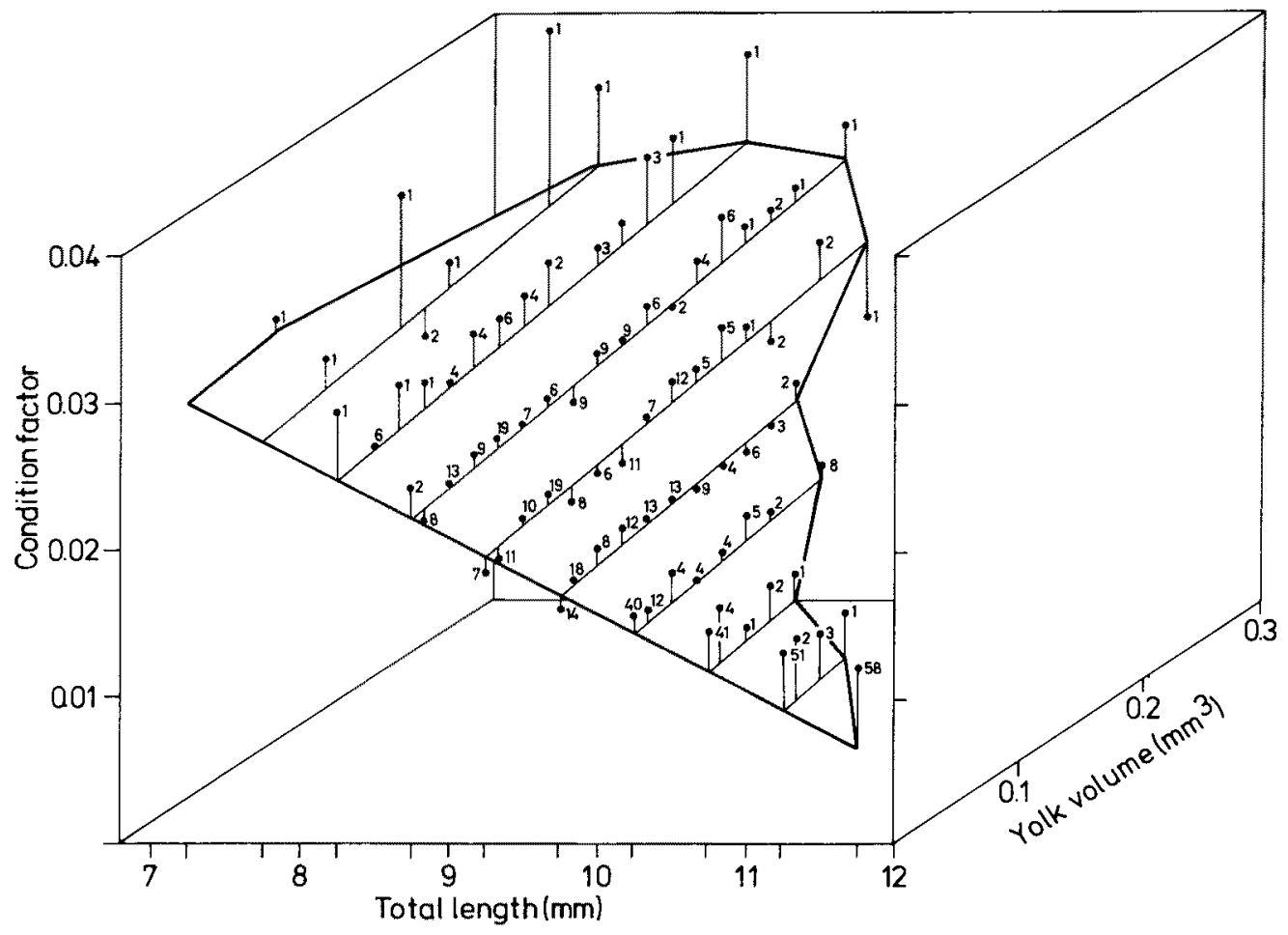

Fig. 2. Condition factors $\left(\mathrm{mg} \cdot \mathrm{mm}^{-3} \cdot 100\right)$ of Pacific herring larvae in relation to yolk sac size $\left(\mathrm{mm}^{3}\right)$ and total length. Full circles are means of several measurements (figures) at a certain total length. Outlined plane indicates correspondance with or deviation from a linear length/yolk sac volume/ condition factor relationship according to the formula $z=0.068-0.0052 x+0.014 y$. $z$ : condition factor; $\mathrm{x}$ : $\mathrm{mm}$ total length; $\mathrm{y}: \mathrm{mm}^{3}$ yolk volume. Vertical lines to full circles indicate deviations of measured data from the calculated plane

growth of the larvae after having reached their lowest condition factors, and after passing through the transitional phase (broken regression line, 1974 at $13.00 \mathrm{~mm} ; 1976$ at $14.00 \mathrm{~mm}$ ).

Apart from the transitional phase between resorption of yolk sac and successful initiation of feeding, development of condition factors in feeding larvae is linear, with the suggestion of a non linear increase beyond a total lenght of $26 \mathrm{~mm}$ (Fig. 1b), a fact also noted by Vilela \& Zijlstra (1971). Linear increase of CFs in feeding larvae has also been observed under experimental conditions by Laurence (1974) in early larvae of haddock Melanogrammus aeglefinus.

In Figure 1b, we notice among the larvae, sized 12 to $24 \mathrm{~mm}$, several "dropouts" with extremely low condition factors, some being below 0.01 . This is possibly an aftereffect of the low food availability and the resulting poor condition of the 1976 larvae during the "critical period", because the condition factors of feeding fish larvae depend on the density of potential food organisms. Once prey concentration sinks below a certain level the condition of larvae starts to deteriorate (Laurence, 1974).

Observations on the low condition factors of sea caught larvae have also been 
Table 1. Clupea harengus palassi. Variation of condition factors of herring larvae from Departure Bay, Canada, with larval development. Water temperature: $9.3-9.4{ }^{\circ} \mathrm{C}^{*}{ }^{*}$ yolk sac larvae; SD: standard deviation; $\mathrm{n}$ : number of larvae measured; CF: condition factor (mg $\left.\times \mathrm{mm}^{-3} \times 100\right)$

\begin{tabular}{|c|c|c|c|c|c|c|c|}
\hline \multicolumn{4}{|c|}{1974} & \multicolumn{4}{|c|}{1976} \\
\hline $\mathrm{mm}$ & CF & $\mathrm{SD}$ & $\mathrm{n}$ & $\mathrm{mm}$ & CF & $\mathrm{SD}$ & $\mathbf{n}$ \\
\hline * $8.3-8.35$ & 0.0284 & \pm 0.0042 & 10 & * 8.45 & 0.0301 & \pm 0.0041 & 5 \\
\hline * 8.45 & 0.02635 & \pm 0.0013 & 4 & - 8.79 & 0.0251 & \pm 0.0032 & 9 \\
\hline * 8.8 & 0.0247 & \pm 0.0027 & 13 & * 9.18 & 0.0202 & \pm 0.0021 & 10 \\
\hline * 9.1 & 0.0222 & \pm 0.0033 & 10 & $* 10.00$ & 0.0163 & \pm 0.0012 & 11 \\
\hline * 9.2 & 0.0226 & \pm 0.003 & 8 & 11.39 & 0.0124 & \pm 0.0012 & 11 \\
\hline - $9.7-9.75$ & 0.0187 & \pm 0.0019 & 12 & 12.58 & 0.0120 & \pm 0.00098 & 24 \\
\hline$\cdot 10,00$ & 0.0160 & \pm 0.0021 & 5 & 13.79 & 0.0123 & \pm 0.00070 & 10 \\
\hline 10.5 & 0.0147 & \pm 0.0017 & 10 & 13.97 & 0.0120 & \pm 0.00098 & 10 \\
\hline $11.0-11.05$ & 0.0147 & \pm 0.0013 & 11 & 14.48 & 0.0125 & \pm 0.0016 & 11 \\
\hline 11.4 & 0.0141 & \pm 0.0012 & 6 & 15.34 & 0.0145 & \pm 0.0024 & 13 \\
\hline $12.4-12.6$ & 0.0138 & \pm 0.00083 & 6 & 16.21 & 0.0156 & \pm 0.0018 & 12 \\
\hline 12.95 & 0.0137 & \pm 0.00075 & 6 & 17.24 & 0.0167 & \pm 0.0018 & 25 \\
\hline $14.6-14.65$ & 0.0152 & \pm 0.0016 & 8 & 18.62 & 0.0157 & \pm 0.0022 & 5 \\
\hline $15.35-15.4$ & 0.0174 & \pm 0.0034 & 8 & 19.31 & 0.0179 & \pm 0.0022 & 14 \\
\hline 15.9 & 0.0172 & \pm 0.002 & 7 & 21.03 & 0.0192 & \pm 0.0034 & 11 \\
\hline $16.2-16.25$ & 0.0178 & \pm 0.00087 & 5 & 23.28 & 0.0198 & \pm 0.00099 & 6 \\
\hline 16.9 & 0.0179 & \pm 0.003 & 6 & $24.14-24.48$ & 0.0197 & \pm 0.0023 & 12 \\
\hline $17.2-17.45$ & 0.0182 & \pm 0.0014 & 6 & 26.50 & 0.0248 & \pm 0.0019 & 5 \\
\hline
\end{tabular}

reported by Blaxter (1971) who collected Clyde Sea herring larvae displaying condition factors as low as 0.009 , therewith being below Blaxter's laboratory determined CFs exhibited by larvae beyond the experimental starvation level. His own findings lead Blaxter (1971) to the following conclusion: "It must at present remain somewhat uncertain how valid comparisons are between experimental and sea-caught material".

In any case our findings and also the data provided by Shelbourne (1957) and Blaxter (1971) support the assumption that larval condition and also the rate of survival depend very much on how the larvae pass the "critical period". Although after having passed the obstacle "critical period" the condition factors in the 1974 and 1976 larvae develop at the same rate (Fig. 1). Table 1 shows, that the 1974 larvae at a given length always have better condition factors than the 1976 larvae. The occurrence of the "dropouts" in 1976 further demonstrates the lasting effects of the food shortage during the critical period in the 1976 larval population. Thus, effects on the later recruitment of this year class might have been expected (see also May, 1974). But when comparing the situation, theoretically to be expected, with the real one, we learn that the 1976 year class of the Gulf of Georgia herring population yielded an extremely good recruitment in 1979 and 1980, being twice as good as the recruitment resulting from 1974 (Hourston \& Schweigert, 1980).

\section{LITERATURE CITED}

Beckmann, W. C., 1948. The length-weight relationship factors for conversions between standard and total lengths, and coefficients of condition for seven Michigan fishes. - Trans. Am. Fish. Soc. $75,237-256$. 
Blaxter, J. H. S., 1971. Feeding and condition of Clyde herring larvae. - Rapp. P.-v. Réun. Cons. perm. int. Explor. Mer 160, 128-136.

Blaxter, J. H. S. \& Hempel, G., 1963. The influence of egg size on herring larvae (Clupea harengus L.). $-J$. Cons. perm. int. Explor. Mer 28, 211-240.

Blaxter, J. H. S. \& Staines, M. E., 1971. Food searching potential in marine fish larvae. In: Fourth European Marine Biology Symposium. Ed. by D. J. Crisp. University Press, Cambridge, 467-485.

Ehrlich, K. F., Blaxter, J. H. S. \& Pemberton, R., 1976. Morphological and histological changes during growth and starvation of herring and plaice larvae. - Mar. Biol, 35, 105-118.

Hempel, G. \& Blaxter, J. H. S., 1963. On the condition of herring larvae, - Rapp. P.-v. Réun. Cons. perm. int. Explor. Mer 154, 35-40.

Hjort, J., 1914. Fluctuations in the great fisheries of northern Europe viewed in the light of biological research. - Rapp. P.-v. Réun. Cons. perm. int. Explor. Mer 1, 5-38.

Hourston, A. S. \& Schweigert, J. F., 1980. Cohort analysis vs direct measures of the abundance of major populations of herring on Canada's west coast, 1971-1979. - Tech. Rep. Can. Fish. Aquat. Serv. 959, 1-15.

Kennedy, O. D. \& LeBrasseur, R., 1977. Microplankton in the Straits of Georgia. I. Pelagic diatoms in Departure Bay and adjacent waters. - Ms. Rep. Fish. Res. Bd Can. 1418, 1-43.

Laurence, G. C., 1974. Growth and survival of haddock Melanogrammus aeglefinus larvae in relation to planktonic prey concentration. - J. Fish. Res. Bd Can. 31, 1415-1419.

May, R. C., 1974. Larval mortality in marine fishes and the critical period concept. In: The early life history of fish. Ed. by J. H. S. Blaxter. Springer, Berlin, 3-19.

Rosenthal, H. \& Hempel, G., 1970. Experimental studies in feeding and food requirements of herring larvae (Clupea harengus L.). In: Marine food chains. Ed. by H. Steele. Oliver \& Boyd, Edinburgh, 344-364.

Rounsefell, G. A. \& Everhart, W. H., 1953. Fishery science: its methods and applications. Wiley, New York, $444 \mathrm{pp}$.

Shelbourne, J. E., 1957. The feeding and condition of plaice larvae in good and bad plankton patches. - J. mar. biol. Ass. U. K., 36, 539-552.

Vilela, M. H. \& Zijlstra, J. J., 1971 . On the condition of herring larvae in the central and southern North Sea. - Rapp. P.-v. Réun. Cons. perm. int. Explor. Mer 160, 137-141. 